\title{
The planning and reflection of police use of force training: a German case study
}

\author{
Mario S. Staller ${ }^{1} \mathbb{D} \cdot$ Swen Koerner ${ }^{2} \mathbb{D} \cdot$ Valentina Heil $^{3} \cdot$ Andrew Abraham $^{4} \mathbb{D}$. \\ Jamie Poolton ${ }^{4}$ (B)
}

Accepted: 11 February 2022

(c) The Author(s) 2022

\begin{abstract}
The current study aimed to elicit the planning and reflecting processes of police trainers with regards to the delivery of police training. Four police trainers were explicitly asked about their planning for and reflecting on training sessions. In total 34 interviews were conducted (17 pre, 17 post) and analysed. The results indicated that police trainers employ two main strategies to progress their learners towards the aims of the training session. First, they focus on making the learning experience fun and second, they point out the relevance of the to be learnt skills by creating the demand, showcasing mistakes and then subsequently focusing on developing the needed skills in isolated contexts. However, the data indicated that police trainers were generally deficient in their capability to set training session objectives and to align their delivery of training in a coherent and effective way. Furthermore, higher levels of reflection of the delivery of the training session were almost absent. The results identify a need for professional development for police trainers in the areas of planning and reflection.
\end{abstract}

Keywords Planning $\cdot$ Reflecting $\cdot$ Police training $\cdot$ Use of force training $\cdot$ Conflict management training

Mario S. Staller

mario.staller@hspv.nrw.de

1 Department of Police, University of Applied Sciences for Police and Public Administration North Rhine-Westphalia, Aachen, Germany

2 Department of Training Pedagogy and Martial Research, German Sport University, Cologne, Germany

3 Department of Psychological Sciences, University of Liverpool, Liverpool, UK

4 Institute for Sport, Physical Activity and Leisure, Leeds Beckett University, Leeds, UK 


\section{Introduction}

In the law enforcement domain recruits, regular officers and specialised personal regularly engage in practice geared towards developing the skills to cope with different operational situations, ranging from non-conflictual police-citizen encounters to use of force situations (Birzer 2003; Nota and Huhta 2019). Police trainers are in charge of planning, delivering and reviewing the respective training sessions (Cushion 2020; Staller and Zaiser 2015). This process-in line with current conceptualisations of coaching (Lyle 2018a)—is a decision-making process at its core (Abraham et al. 2006; Lyle 2002; Cushion et al. 2003; Abraham et al. 2015). Police trainers, as coaches, draw from a number of knowledge structures to inform their decision-making when planning, delivering and reflecting (Abraham and Collins 2011a; 2011b). However, research in the context of police training indicates, that police trainers do not regularly engage in planning and reflecting processes (Cushion 2020). In order to further investigate these findings, the current study focuses on how police trainers actually plan and reflect on their training sessions and the relative depth of their reflections. By expanding the methodology employed by Cushion (2020), the current study presents interview data of discussions stimulated by the delivery of police training in Germany reported elsewhere (Staller et al. 2021a, b, c).

\section{Planning training sessions in police training}

When police trainers plan their coaching, a key aspect is knowing what learners should be able to know and do as a result of coaching (Staller et al. 2021a, b, c). The intended learning objectives arise from the analysis of the learners needs relative to his/her current context and form the basis for long-, medium- and short-term plans with specific outcome, performance and process goals. These objectives serve as a reference points from which coaches can monitor and adjust their planning, delivery and reflection (Abraham et al. 2015). As such, planning provides a "tentative map" to follow (Till et al. 2019), providing a sense of direction and expectations against which current development can be continually monitored, on which alternate coaching strategies can be decided upon in order to accommodate and from which responses to changing needs of learners or contextual changes can be developed (e.g. resources). Coaches can only intervene if the need to act is noticed within long-, medium- or short-term planning or, more immediately, within the actual training activity. In order to notice the need to act, coaches have to be continuously attentive to moments of importance or disruption. Engaging in deliberate and purposeful planning can help coaches to detect anomalies by having clear expectations against which current observations of the reality can be compared against and that might otherwise be overlooked (Jones et al. 2013). Within the teaching and coaching process, the capacity to think in this manner while events are happening has been described as reflectionin-action (Martindale and Collins 2012; Schön 1983). Improving the clarity of 
expectations before a coaching event facilitates reflection-in-action, and thus provides an important stimulus for reflection after the coaching event; described as reflection-on-action (Schön 1983; Kovacs and Corrie 2017).

Coaching is a continuous planning, delivery and reflection process (Abraham et al. 2015). To help police trainers cope with the ongoing demands of a dynamic teaching learning environment (Till et al. 2019; Kiely 2012; Abraham et al. 2015) the Coaching Practice Planning and Reflective Framework (CPPRF) has been developed (Muir et al. 2011; Till et al. 2019). It can be understood as a thinking tool to help coaches clarify their expectations and encourage connections between the desired objectives and coaching strategies. In particular the CPPRF encourages thinking and reflection around the (a) intended learning objectives (on a group / individual level), (b) the design of learning activities, (c) coach behavioural strategies and (d) learner engagement. As a planning tool, the CPPRF encourages coaches to think about their coaching goals and the alignment with learner needs and wants (the who), the field-specific demands (the what) and the learning environment (the how) to clarify their expectations. Furthermore, coaches are encouraged to consider how each coaching interaction is nested within the long-, medium- and short-term objectives of learners' development (Abraham and Collins 2011a). The intra-coordination of session activities with the inter-coordination of sessions over a period of time to progress the learner towards agreed overarching goals is referred to as constructively aligned learning practice (Abraham et al. 2015; Biggs 1996).

In police training, the on-going complex process of planning, delivering and reflecting as the heart of coaching best practice (Till et al. 2019; Muir et al. 2015; Abraham and Collins 2011a) has not been fully acknowledged (Staller and Körner 2019). However, attempts to incorporate practical coaching models to frame the delivery of police training have begun to emerge (Nota and Huhta 2019; Körner and Staller 2018; Koerner and Staller 2021, a, b, ctaller 2021). Police trainers need to exhibit the ability to integrate ideas from the interdependent areas of coaching knowledge (e.g. police-specific content knowledge, knowledge about skill acquisition, motivation etc.) to inform their reasoning and decision-making when they plan, deliver and reflect on police training sessions (Till et al. 2019). This includes identifying the target performance in relation to the learners' current state to formulate input demands as well as performance, process and outcome goals (Abraham and Collins 2011a; Till et al. 2019; Abraham et al. 2015). This includes a careful consideration of the "who", "what" and "how" to develop a coaching plan that is coherent, progressive and nested in the bigger picture of a competent police officer. However, the study of how coaches plan, deliver and reflect is scarce, particularly in the domain of police training. Some data is provided by Cushion (2020) from his observations of officer safety training in the UK. This work surmised that police trainers invested limited time in discussions about the planning and delivering of courses and did not explicitly consider any criteria for delivery success, such as outcome, performance or process goals. Cushion (2018) concludes, that "training was in a self-confirming 'loop'" (p. 7) manifesting traditional training approaches, consisting of large amounts of teacher-centred practices aiming at developing skill in an isolated fashion. Such approaches are regularly observed in police training (Basham 2014; Birzer 2003; Cushion 2020; Staller, et al. 2021a, b, c). This lack of 
self-reflection has recently been outlined as one of the major obstacles in advancing the delivery of police training (Staller et al. 2019a, b).

\section{Coach learning: reflection and learning-loops}

From a coach learning perspective, indications of a lack of reflection in police training coaching practice (Cushion 2020; Staller et al. 2019a, b) points towards that learning in police use of force coaching lacks awareness of underlying assumptions (Brookfield 2013), such as the underlying pedagogical approach (Birzer 2003; Körner and Staller 2018) or the inclination towards a more warrior or guardian-oriented policing approach (McLean et al. 2019; Staller et al. 2019a, b). Being aware of the underlying assumptions of ones coaching practice is a necessary ingredient for higher levels of learning (Argyris 2003; Tosey et al. 2012). "Higher" levels of learning in this context means that new perspectives with a successively wider scope are involved. Tosey et al. (2012) conceptualized these higher levels in recursive loops that function as feedback loops from all levels for previous levels and vice versa. Whereas single-loop learning is concerned with doing things right, double-loop learning takes place by examining and altering the governing causal and prescriptive assumptions of such practices (Argyris 2003), answering the question of "Am I doing the right things?". For example, a single-loop reflection of a police trainer, Oliver, teaching a take-down technique for a resisting citizen revolves around questioning himself about when to intervene in case a learner does not perform the technique like it was shown by him. Further reflecting on a higher level on the same example will incorporate questioning the assumption of why our trainer adheres to an ideal technique. Oliver becomes aware that he was taught in a traditional linear him/herself leading to the assumption of an ideal technique (Moy et al. 2015). Our trainer now becomes aware of other governing assumptions like non-linear pedagogy and is able to connect the underlying assumption with his current practice, resulting in double-loop learning. In the current training session, our police trainer now guides the learner to find their individual solution to taking down a person rather than impressing upon them a prescribed technique. By further acknowledging, challenging and unpacking assumptions with increased awareness of the relativeness and role of theoretical concepts a higher level of reflection and learning takes place; this has been described as a triple loop learning process (Tosey et al. 2012). The guiding question here is "How do I decide what is right?", involving questioning of what Brookfield terms "paradigmatic assumptions" (Brookfield 2017): The structuring assumptions we employ to order the world into fundamental categories and that are hard to recognize. In our example, our police trainer Oliver-triple-reflecting on the situation-asks himself about when and why to apply a non-linear or linear approach to learning. He becomes aware that his drive towards a specific pedagogical approach is partially fuelled by what other coaches in his milieu favour at the moment. Oliver now starts asking why, when and for who he should apply a specific pedagogical approach. Reflecting on his current problem, he thinks about the pros and cons of linear and non-linear approaches to training in the context of the specific situation he encounters with his learner and reaches the tentative conclusion that he 
will currently employ a more linear approach to training with more augmented feedback on the take-down execution, because he feels, that his learner has difficulties in coordinating his movements, lacks creativity and is easily frustrated when he is not immediately succeeding in taking down his partner.

\section{Aims and scope of the study}

The reflective practitioner has been highlighted as a desirable outcome of coach education in police training (Körner and Staller 2018). Reflective practice is generally considered as a continuous interaction between planning and delivery that deepens understanding of the learner's own practice and experience and leads to more skilled practice (Schön 1983). From this viewpoint it seems problematic that police trainers seem to lack planning and reflecting processes as evidenced by Cushion (2018). However, it cannot be inferred that police trainers do not engage in planning and reflection of their teaching and delivery of programs from observation studies alone. Even though they do not have the time to discuss issues with each other (Cushion 2020) it can be assumed that they still engage in some form of planning and reflecting process. However, the content and the thought processes associated with these procedures is unknown. As such, the current study aims at eliciting these planning and reflecting processes by explicitly asking police trainers about their planning and reflecting on their training sessions.

\section{Methods}

The case study was conducted at a German Police Academy, where the recruits of the Hessian State police are trained and educated. The research reported builds upon observational study data collected during a case study of police training (Staller et al. 2021a, b, c). A study section with five full days of police training for two groups provided the analytical frame of the study with the object being the process of training (Thomas 2011), resulting in approx. $46 \mathrm{~h}$ of observed police training. The training was delivered by 4 police trainers with a mean age of $39(S D=6.16)$ years and an average of $13.00(S D=9.87)$ years of experience as a police trainer. All police trainers were male. The sample of police trainers consisted of the complete police trainer staff that delivered the training within the observational study. As such, the current study was constrained by the available timeframe and access to the police trainers within the observational study.

\section{Data collection}

Before and after the training sessions, the police trainers were interviewed using a semi-structured approach. Prior to the sessions, the interview was structured using the CPPRF. Specifically, questions pertained to (a) the place of the sessions within the bigger picture of police training; (b) the planned structure of the learning activities; (c) the planned teaching behaviours; and (d) the planned strategies to engage 
recruits in learning activities. After the sessions, police trainers were asked to comment on the training session. The complete data set comprised of pre- and postinterviews of 17 training sessions (5 Self-defence and Arrest training; 4 Firearms training; 8 Tactical training). The interviews were recorded and transcribed verbatim and subjected to further analysis. Copies of the anonymised interview transcripts are available upon request.

\section{Data analysis}

The analysis of the interviews was based on sound qualitative research techniques, using qualitative thematic analysis (Braun and Clarke 2006). The analytical strategy was chosen according to the objectives of the study aiming at investigating the broader context of planning from the coaches' perspective and identifying the respective thematic focus. Interviews were analysed using MAXQDA data analysis software (Version 18.2.0). The analysis involved independently familiarizing oneself with all of the data by reading transcriptions and listening to interview tapes. Transcripts were examined both inductively and deductively, with the deductive analysis based on the research question (CPPRF, single-loop, double-loop and triple-loop reflection on the training session). Raw data themes were identified and built up into meaningful themes and sub-themes. The number of times a raw data theme was referenced (a meaning unit) was tallied. Subsequently, samples of these data sets were re-examined by another member of the research team (SK). Issues of contention between the researchers (MS, SK) were resolved using questioning and debate (Abraham et al. 2006).

\section{Results}

The higher order themes included planning and considerations before the training session and reflection levels about the training session (see Table 1: Results of qualitative analysis of interviews displaying hierarchical themes). Concerning the planning of the training session, results revealed fiver lower order themes categorized according to the CPPRF: (a) the learning objectives of the training session, (b) the embedding in the overall structure of police training, (c) the structure of the specific training session, (d) the planned coach behaviour to support the learner in reaching their aims of the session and (e) the facilitation of learner engagement. Reflections of the training session included single-loop reflections and one incident of doubleloop reflection.

\section{Planning and considerations before the training session}

With regards to the learning objectives of the training session coaches most often referred to the topic of the session (e.g. weapon handling, arrest techniques): 


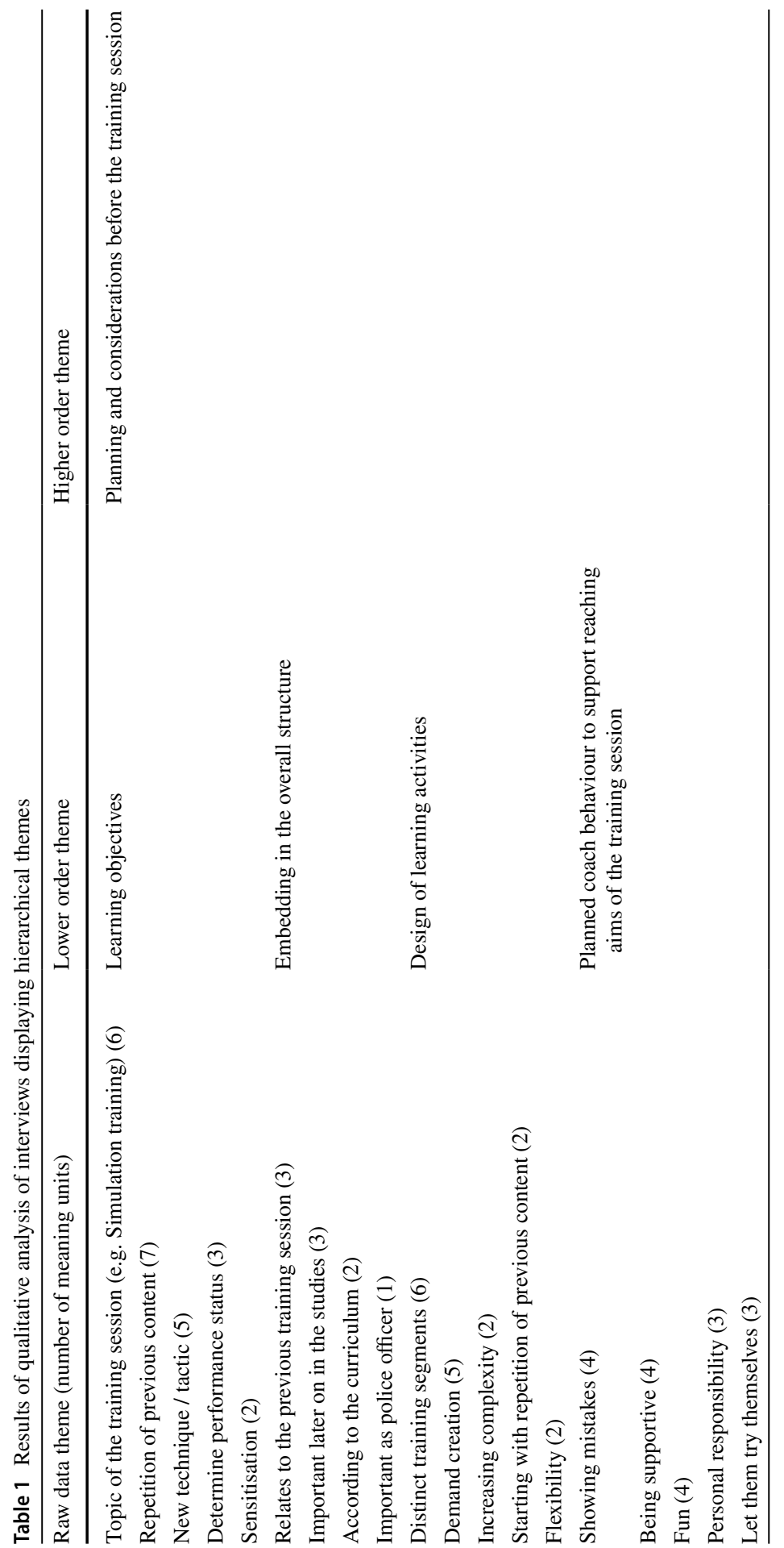




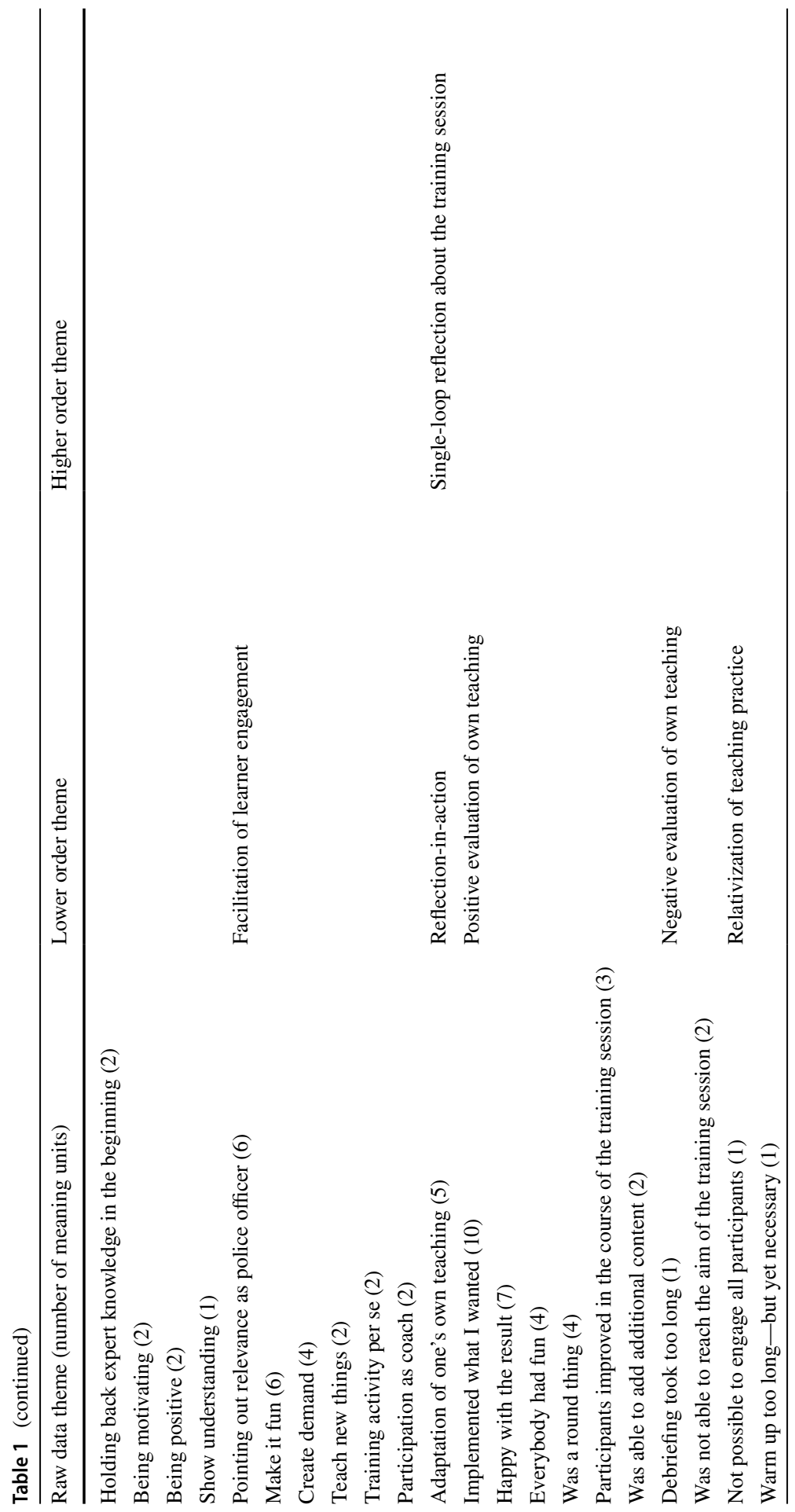

站。 


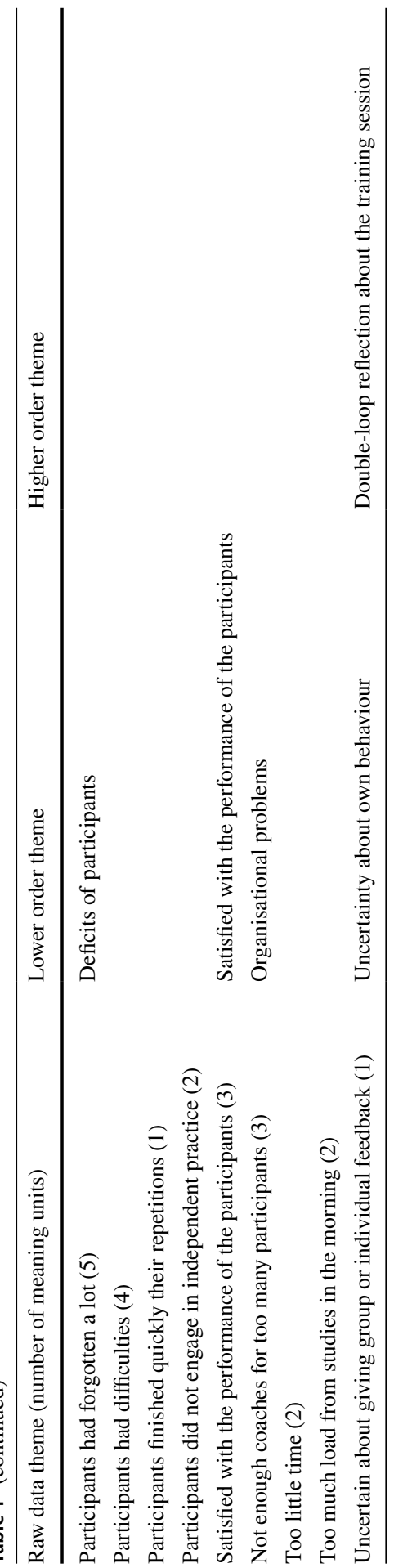


"The goal is the shooting with two weapon systems, long weapon, short weapon, and to practice switching between the weapons." (Day 3, Firearms training)

What learners should achieve by the end of a training session was not mentioned. Reference was also made to the repetition of previous content, and the introduction of new techniques or tactics.

"Today is a complete repetition, refreshment of the basic training and of course then one or two additional techniques or extensions of the basic knowledge." (Day 1, Tactical training)

Coaches provided scarce information about how the specific training session is embedded in the overall structure of police training. They mainly referred to the content relating to previous training sessions and the content of the upcoming session being an essential element of police training, which will be built upon in future training sessions:

“Then we'll pick up where we left off last week." (Day 3, Tactical training)

However, coaches gave no further detail on how specifically the content fits into the overall structure of the curriculum.

Concerning the design of learning activities, coaches often described distinct training segments that appeared to be isolated from each other. For example, the self-defence and arrest coach outlining the structure of a training session on day 4:

"A short general warm up; then I will explain the circuit training. Then we do techniques. Then repeating the arrest concept. We finish with boxing." (Day 4, Self-defence and arrest training)

Coaches provided no rationale for this structure. Another common point of reference was the "creation of demand". Coaches refered to this term, when they created training tasks, where learners failed due to a technique or tactic, that they had not been introduced to yet. Demand creation was especially prevalent in tactical training:

"Demand generation scenario, as I said. Then new things like opening doors and team behaviour in a 360 environment." (Day 3, Tactical training)

The creation of demand was also identified within the context of the planned behaviour of the coach and applied by use of the strategy of showcasing the recruits' mistakes. Police trainers described this as a strategy with the intent to support the learners:

"Yes, to show mistakes, and to improve them. That they can then better apply the techniques." (Day 5, Self-defence and arrest training)

Coaches planned at being supportive in correcting the mistakes. They articulated an intent to help the recruits in improving their mistakes and to perform better: 
"[I want] to always stand aside to answer the questions, to do justice to everyone, to clear up all mistakes, to uncover all mistakes" (Day 3, Tactical training)

The importance of projecting "fun" was mentioned several times as a planning principle. A coach referred to having fun himself, in order to make the training session fun for the students.

"Having fun. That I have fun in class myself and I think that's very important.

When I have fun in class, so that my colleagues also notice that. So together we then can achieve goal of the training session in connection with fun." (Day

2, Tactical training)

The element of fun was also stated quite often with regards to facilitating the engagement of the learners.

"Going in and out of class with fun". (Day 5, Self-defence and arrest training)

Besides having fun, coaches also planned in pointing out the relevance of the content of the training session for the recruits as police officers. Specifically, police trainers mentioned the relevance with regards to training content for worst case scenarios, where officers do not have a second chance if they fail (e.g. a lethal knife attack).

"They [the recruits] should be aware that they need to be motivated. Because in a worst-case scenario we don't have a second chance. Here you must succeed the first time, otherwise they get injured or even die. And I think that should be the greatest motivation." (Day 1, Tactical training)

Besides skills for worst-case scenario, skills that are needed on a daily basis were also pointed out as relevant for the recruits:

"The need to know the importance of the arrest technique. That they need the technique in their daily life. Because of that, they should practice accordingly and be serious during the training session." (Day 3, Self-defence and arrest training)

Coaches stated a belief that the relevance the content itself provides the motivation to engage the learner with the subject material.

"The training content must be enough motivation." (Day 5, Tactical training)

Taken together, concerning the planning before training sessions the results showed, that police trainers reported a specific topic as the learning objective without referencing what the learner should achieve during the session. The topic was embedded in the long-term development insofar that the current content follows the previous content and that it is necessary for the content in the next training session. The learning activities were designed and structured as isolated elements. Police trainers reported they designed training tasks where recruits fail in order to create demand and to highlight their mistakes. Being supportive and having fun themselves were reported as dominant planned coaching behaviours. Finally, learner 
engagement was reported to be facilitated by the relevance of the content and the element of fun.

\section{Single-loop reflection about the training session}

The interviews immediately following the training sessions resulted in a number of different types of reflections, which, for the most part, were single-loop in nature. The interviews showed that coaches reflected upon their reflection in-action while conducted their training session. Police trainers mentioned that they adapted their teaching when they encountered problems in the delivery of the session. Coaches spoke of adapting the task difficulty when they saw that recruits were not experiencing success of hitting the assigned target area. A firearms trainer provided a rationale for this decision.

"[...] in the further process I designed the exercises a bit simpler, more balanced, in order to give a positive feeling" (Day 4, Firearms training)

Concerning adaptation in other fields of police training, one coach of tactical training recalled that he scanned the recruits for their motivation and how they were engaging to adapt his program accordingly.

"[...] I watched the recruits, I looked how motivated they are, to what extent they participate." (Day 1, Tactical training)

The tactical trainer further reported that he perceived that the recruits were tired from the lessons in the morning and adapted the pace of the training session accordingly by teaching "step-by-step".

Reflecting on their teaching performance, police trainers evaluated their teaching very positively in terms of being able to implement the specific planned content:

"And yes, so it worked out well, training goal achieved. So all components that we had planned, they were implemented accordingly". (Day 1, Tactical training)

It was often mentioned that they were pleased with the result of the session and that the delivery itself was fun. One police trainer regularly mentioned that the session itself was a "round thing", meaning that everything worked out nicely without any problems.

"Yes, it was a round thing today". (Day 3, Self-defence and arrest training)

The analysis revealed one account in which a police trainer negatively evaluated an aspect about their teaching. It was an admission from the coach that they did not achieve the aim of the training session. They attributed this to an organisational problem.

"Then the main part, the [entering of] unclear areas I had been able to implement. But, I have to admit that due to the fact that I am alone and the size of the group I did not completely meet the aim of the training session." (Day 3, Tactical training) 
Although this was the only negative single-loop reflection of police trainers teaching performance recorded; there were accounts of relativization of teaching practice. These accounts gave the impression that coaches were not explicitly satisfied with a session; however, a rationale was put forward to relativize the decisions made. In the following example, the coach appeared to be well aware of the inclusion of a very long warm-up that included a fitness circuit. Even though this part of the session was not connected to the curriculum content of self-defence and arrest training, the coach provided a rationale for his decision:

"The warm-up might have been a bit long, but I think it's necessary to keep people physically fit." (Day 3, Self-defence and arrest training)

Concerning the performance of the learners, coaches pointed out the deficits of the recruits on a regular basis. It was mentioned that the recruits had forgotten a lot:

"The problem is after one week a lot has already been forgotten." (Day 3, Tactical training)

The perception that recruits had forgotten or were not able to perform the taught skills was attributed to periods of field training where recruits did not have access to police training in an academy setting. However, this was not an argument for the problem that recruits were perceived having forgotten the content from a training session two weeks earlier.

Coaches also pointed out deficits in the motivation of the young officers to practice, even though it was clear that their skills needed improving. A firearms coach complained that recruits did not use the opportunity to practice with inert weapons at the back of the shooting range. Instead, they waited passively until it was their turn.

"What I didn't like was that the offered dry training with red weapons was not used [by the recruits], because you could see that there were still difficulties in shooting while moving”. (Day 3, Firearms training)

Although coaches reported deficits in skill retention and motivation, the coaches did also comment on the satisfactory performance of recruits over the course of a training session:

"And in the further process [in the training session] shooting while moving and the weapon change were constantly repeated and in the end I had a good impression that they can shoot well while moving and when they have to change their weapon." (Day 5, Firearms training)

However, reflections on satisfactory performance were reserved for advances made by recruits within a session. It is noteworthy that coaches did not mention performance improvements between the training sessions.

Several coaches mentioned organizational problems impacting their delivery of police training, including too little time for training to be effective, the general load, both cognitive and physical, recruits had to endure on a training day, and a 
low coach to recruit ratio. For example, after a tactical training session a coach commented on the class size too big for him as a single coach.

"But due to the size of the group, I couldn't get all the way to the aim of the training session. And when larger study groups come, it will get more difficult." (Day 2, Tactical training)

The coach, in this example, is referring to an anticipated rise in numbers of recruits in the near future. He further explained, that due to current increases in the recruitment of police officers large group sizes will be the standard for coaches to handle.

\section{Double-loop and triple-loop reflection about the training session}

There was one account of uncertainty regarding an adopted coaching behaviour that can be considered a double-loop reflection. Specifically, a coach mentioned a discussion with his peers about addressing issues with a recruit individually or in front of the whole group:

"We have also just sat down ourselves within the coaches and discussed that we might have been able to optimize a few things. Possibly we should address things in front of the whole group and not only individually, thus problems, so that they don't arise in the next group, because we have already seen them visually or heard them from the others." (Day 1, Tactical training)

This was the only evidence in the interviews that suggested levels of reflection that went beyond single-loop learning. The data showed not events of triple-loop reflection.

\section{Discussion}

The current study investigated the planning and reflecting processes of police trainers around the delivery of their training sessions. The interviews of the police trainers provided insights into the question of (a) what and how they planned for the delivery of their training session and (b) how and to what level they reflected upon the training session.

\section{(Reflective) planning decisions}

Concerning police trainers planning up-front of their training sessions to progress police recruits towards their long-term development goal, the results yielded several findings that related to the interdependent areas of the CPPRF (Muir et al. 2015, 2011). Given the centrality of aligning the controllable elements of a training session (i.e. the structure and design of learning activities and coach behaviour) to maximise learner engagement with the long-term goals of learner development, we first discuss the alignment of the learning objectives in the long-term development 
plan before, secondly, focusing on strategies of trainers to maximise learner engagement in order to reach their learning objectives.

The interviewed police trainers did not appear to have a clear conceptualization of the learning objectives of the training session and its place within the macrostructure of police training. Connections to the long-term development plan were only made concerning to the last and the following training session. The rationale for the practicing on a specific training content (e.g. a takedown) was that it followed the last content and precedes the next. This likely contributed to the isolated, disconnected elements of the curriculum that were observed in the observational study of the police trainers' delivery (Staller et al. 2021a, b, c). This disconnection between elements of the curriculum has also been reported by other studies in the context of policing (Cushion 2020). This disconnection is problematic insofar that no systematic progression towards an overall development goal is possible. A constructive alignment of a police training program would demand that the intended learning objectives arising from the police officers needs in the field become the basis for designing long-, medium-, and short-term plans. These learning objectives then provide a key reference point from which police trainers and decision-makers can monitor and adjust the effectiveness of their programs, (Abraham et al. 2015; Staller et al. 2021a, b, c). The key reference point in our study seemed to be the number of the training session, with the police training manual stating what should be taught in which training session (Staller et al. 2021a, b, c), an approach that was also evidenced by Cushion (2020). This suggests that the purposeful alignment and structure of training content seems an issue to be optimized within police training coach learning.

Second concerning the controllable elements of coaching (i.e. coaching behaviour \& activity design), the police trainers focused on two overarching aspects that they planned to compliment through their coaching behaviour and the structure and design of learning activities: (a) making the learning experience fun and (b) the relevance of the to be covered material.

As it concerns "fun", police trainers tried to have fun by themselves and to have fun with the recruits. Police trainers provided no explanation of how they create a fun learning environment. However, as interview data from recruits about the same coaches in another study showed (Staller et al. 2021b) police trainers regularly achieve this aim. Aligning coaching behaviours to make the learning fun is in line with current recommendations (Beni et al. 2017), since having fun has recurrently been stated as a reasonto participate in youth sports and its absence as a reason for dropout (Visek et al. 2015; Bengoechea et al. 2004). Furthermore, it has been described as central to meaningful activity experiences (Jakobsson et al. 2014; Smith and Parr 2006). However, Beni et al. (2017) recommend not to prioritize fun at the expense of other criteria of meaningful experiences.

Police trainers also plan to provide meaningful experiences by providing content, that is relevant and thus meaningful for the recruits. As such, they regularly communicated the relevance of the taught material in order to promote learner engagement. Data from interview studies showed (Staller et al. 2021b) that recruits are motivated by the perceived relevance of the content in police training. However, studies have shown that trainees sometimes perceive that there are differences in the content and 
its delivery between the police training learning environment and the field (Rajakaruna et al. 2017; Renden et al. 2015; Staller et al. 2021a). for developing the skills they perceive they need it may impact motivation. Police trainers seem to be aware of this by employing strategies to bolster the relevance of the taught content. They created learning tasks where recruits were "shot" to create the demand for learning a specific tactic to avoid getting shot. The benefit of learning from errors in complex environments is well-document throughout the literature (Metcalfe 2017; Piggott 2007), particularly, when receiving corrective feedback, including an analysis of the reasoning leading to the mistake (Morrison and Meliza 1999). Police trainers planned for the congruent coaching behaviour by showing the recruits the mistakes they made and by subsequently being supportive in managing the mistakes and prescribngtechniques and tactics.

Police trainers perceived the provided content (techniques and tactics) and the way of provision as useful and hence, relevant for the recruits. Data from the related observational study (Staller et al. 2021a, b, c) showed that police trainers predominately engaged recruits in repetitive, isolated practice with high amounts of corrective feedback. This points towards a problematic issue: That what police trainers think is most effective-technique/tactic to succeed in the field or pedagogical approach to best facilitate learning - is not necessarily the best approach. For example, police trainers design the isolated learning activities with the best intentions, namely to promote learner engagement, since they (the trainers) think that recruits perceive the content and how it is delivered as relevant per se. Police trainers think that through structuring learning of techniques and tactics in these linear isolated processes recruits develop the skills needed (i.e. their long-term development goal). However, research has shown, that diametral to the police trainers' intentions, repetitive and isolated practice does not facilitate learner motivation and engagement within this social milieu (Staller et al. 2021b) and that other pedagogical approaches (e.g. non-linear pedagogy) may be more effective in this specific context (Körner and Staller 2018). Likewise, concerning the content of specific techniques or tactics, interview data repetitively showed that what is learned in training is not necessarily that what is needed in the field (Staller et al. 2021a; Renden et al. 2015; Jager et al. 2013).

To tackle this issue, police trainers have to be aware of their governing assumptions about what is needed and what works in the field (e.g. techniques, tactics, skills) and which pedagogical approach governs their teaching behaviour. Being aware of theses underlying assumptions constitutes the need for double-loop reflection (Tosey et al. 2012; Brookfield 2013).

\section{The depth of reflection}

With one exception, coaches engaged in single-loop reflection when reviewing the training session they had just delivered. Coaches reflected what has happened within the training session based on their causal and prescriptive assumptions (Brookfield 2013). Based on what their assumptions about what should happen in a particular situation and under what conditions a specific behaviour changes, coaches generally 
evaluated the training session positively. At the same time, they pointed towards deficits within the students, especially, that they did not retain taught skills from the last sessions. For coaches, this lack of skill retention provided valuable data concerning the monitoring of their training program. From here adjustments in the planning and delivery of the program can be made in order to further progress towards the long-term goal (Abraham et al. 2015; Otte et al. 2019; Farrow and Robertson 2017). However, in the light of their governing assumptions of what constitutes a good training session (i.e. single-loop reflection), they felt they delivered the training well. It can be assumed that the consequence herein can be seen in the other areas of reflection: if they did well the lack of skill progression within the recruits must be attributed to something else, like organisational problems or the need for more physical fitness, as evidenced by the reported relativization strategies. Indeed, police trainers in a recent interview study (Körner et al. 2019) pointed towards the general deficits of young recruits in our society in explaining what has changed in police training over time. In the light of the current evidence that police trainers mainly engage in single-loop reflection, this may seem to be an adaptive strategy to cope with the monitored lack of skill progression (Vries and Timmins 2015; Martinie and Fointiat 2006; Shultz and Lepper 1996).

The reported incident by one police trainer of being unsure about a specific approach in highlighting the mistake of a recruit, indicates that police trainers do engage in double-loop reflection. However, compared to the extensive amount of single-loop reflection, this may be problematic with regards to delivering effective programs in police training. There is a consensus that effective coaching depends on the coach's ability to continually reflect, adapt and innovate (Gallimore et al. 2014). Not surprisingly, coach education programs in the sport domain are designed to prepare coaches for ongoing learning, emphasizing the importance of having them reflect on problems they encounter within their working environments (Gilbert et al. 2009; Trudel et al. 2010). Teaching critical thinking with regards to one's own coaching practice would involve being alert of the underlying assumptions of practice (Brookfield 2013), setting the base for being able to challenge and refine (if needed) these governing ideas (Argyris 2003; Tosey et al. 2012).

In defence of the police trainers, coaching courses in police training seem not to systematically incorporate elements of reflective practice, in Germany at least (Staller and Körner 2019). In his case study, Cushion (2020) concluded, that "instructors $[\ldots]$ are time pressed and have limited time for reflection on their own practice and are therefore constrained and limited by what they know" (p. 13). Since ongoing critical reflection has been advocated as an important tool for professional practice in law enforcement in general (Christopher 2015) and for police training specifically (Staller and Körner 2019; Körner and Staller 2018), coach development programs should be adapted accordingly.

\section{Practical implications and further research}

The reported data can be geared towards two major issues that are worth considering in order to improve practice. First, our data indicated a lack of constructive 
alignment of the program, resulting in non-specific learning objectives for each session, making it hard for police trainers to plan and adjust their behaviours and the structure and design of learning activities to reach the overarching aims of the training program. In order to improve practice, police trainers and curriculum designers might consider a clearer conceptualisation of a long-term development plan for police recruits. This may involve questioning and reasoning what a competent police officer actually needs concerning his or her operational skills in the field (Rajakaruna et al. 2017). Police trainers also could enhance their ability to coherently align training sessions towards an objective that reaches beyond the last and next training session. However, police organisations have to reflect critically if they provide police trainers with the necessary tools and skills that allow them to constructively align training programs. As such coach development and learning programs in police training may consider focus on (a) the alignment of learning objectives of specific training session to medium- and long-term developmental goals and (b) how coaches then can work towards these aims (e.g. by using the CCPRF).

Second, the current study highlights the problems associated with a lack of higher levels of reflection in police training. Not going beyond single-loop reflection may lead to the manifestation of ineffective training delivery on an individual level, since assumptions about what is needed and which approach is best to achieve it are not questioned. (Körner and Staller 2019). In this light, we suggest that decision-makers and coach developers in police training focus on enhancing the reflexivity of police trainers, especially concerning higher levels of reflection. This includes the ability to reflect on assumptions and models that underpin the chosen learning and coaching process (Chow et al. 2016), including those premises that underpin this reflection process itself (Körner and Staller 2018).

Concerning further research, the results of the current study point out various avenues. With regard to the documented planning and reflection processes of police trainers and the practical implications aiming at coach learning and development a set of further questions arise. Studies focusing on the police trainer may ask: What are the developmental pathways of police trainers? Where do coaches get their knowledge from? What are the formal and informal sources of coaching knowledge in police training? What information concerning coaching do police trainers attend to? How does reflection of the coaching process effect future coaching practice and vice versa: How does learning improve reflection? Research questions aiming at the organisational structures supporting or hindering coach learning and development may include the following: How do police organisation implement coach learning and development for police trainers? How are coaching development courses designed and delivered? Since currently not much is known about police trainer learning and development research into such question would provide valuable insights.

From the perspective of application research (Lyle 2018b) and linked to the capacity of critical reflection of coaches, further research could focus on further developing the reflective practitioner in police training (Körner and Staller 2018; Schön 1983). This may include designing and evaluating programs to enhance reflective thinking within the domain of police training. 
Finally, concerning the underlying assumptions of coaching practice and what is needed as a police officer, we would encourage researchers to further investigate two areas that would provide a basis for double- and triple loop reflection: First, to investigate the benefits and drawbacks of different pedagogical approaches in police training and, second, to further examine the needs of frontline police officers concerning their capability to manage operational situations and conflict.

\section{Limitations}

Our employed methodology has several inherent weaknesses that should be acknowledged. First, the interviews were conducted immediately before and after the training sessions. It may be possible that due to this immediacy police trainers focused on microlevel planning. In both cases this may have limited the depth of the reporting of their planning and reflecting. Second, the interviewers (SK, VH, MS) in this study had a positive reputation within the police academy studied. As a result, it remains possible that coaches wanted to impression manage the opinions of the interviewers (Leary and Kowalski 1990) by presenting their view of competence, resulting in few accounts of negative or critical evaluation of their practice. Future studies may consider highlighting reflexivity as a sign of competence towards the police trainers. Third, the current study relates to data collection in a case study (Staller et al. 2021a, b, c), which took place at a specific time period in the education of young police officers in a specific training institute. Therefore, caution should be taken in generalising the results to other law enforcement agencies at a national or international level. As such, the presented thought processes require validation. Fourth, results may contain gender bias since all trainers interviewed were male. As such, results may be limited to gender-based perspectives calling for further research including female and non-binary police trainers. However, despite the limitation, the employed methodology provided insights into a rather closed process. Especially, since police institutions in Germany have been reluctant to provide access to research coaching in police training (Staller and Körner 2019). For the first time, the current study provides insight into the planning and reflection of police trainers.

\section{Conclusion}

The current study aimed at eliciting the planning and reflecting processes of police trainers regarding the delivery of their training sessions. Our results indicated that police trainers employ two main strategies in order to progress their learners towards the aims of the training session. First, they focus on making the learning experience fun, and, second, they point out the relevance of the to be learnt skills by creating the demand, showcasing mistakes and then subsequently focusing on developing the needed skills in isolated contexts. However, police trainers struggle to conceptualize the immediate learning objectives and embedding them in the long-term development plan for police recruits. Concerning the reflection after the delivery of the sessions, the results yielded that police trainers mainly evaluated their training 
positively and identified deficits in the progress of their recruits' progression. Furthermore, higher levels of reflection, such as questioning governing assumptions and beliefs about training approaches and what is needed for recruits in the field (e.g. long-term development), were almost absent.

Taken together, this indicates a need for higher levels of reflection and learning within police trainers. Not going beyond single-loop reflection processes- "Did I do it right?" -, may lead to the manifestation of ineffective training delivery strategies and providing recruits with content that is not necessarily needed for long term development. Instead, police trainers should also engage in higher levels of reflection questioning - "Am I doing the right things?" and "How do I decide what is the right thing?". In this light, we suggest that decision-makers and coach developers in police training focus on enhancing the reflexivity of police trainers, especially concerning higher levels of reflection.

Acknowledgements We would like to thank all police trainers for participating in the study. We also thank André Kecke for enabling this research project.

Funding Open Access funding enabled and organized by Projekt DEAL.

\section{Declarations}

Conflict of interest We have no known conflict of interest to disclose.

Open Access This article is licensed under a Creative Commons Attribution 4.0 International License, which permits use, sharing, adaptation, distribution and reproduction in any medium or format, as long as you give appropriate credit to the original author(s) and the source, provide a link to the Creative Commons licence, and indicate if changes were made. The images or other third party material in this article are included in the article's Creative Commons licence, unless indicated otherwise in a credit line to the material. If material is not included in the article's Creative Commons licence and your intended use is not permitted by statutory regulation or exceeds the permitted use, you will need to obtain permission directly from the copyright holder. To view a copy of this licence, visit http://creativecommons.org/licen ses/by/4.0/.

\section{References}

Abraham, Andrew, and David J. Collins. 2011a. Effective Skill Development: How Should Athletes' Skills Be Developed. In Performance Psychology: A Practitioners Guide, ed. Angela Button and Hugh Richards, 207-229. New York: Churchill Livingstone.

Abraham, Andrew, and David J. Collins. 2011b. Taking the Next Step: Ways Forward for Coaching Science. Quest 63 (4): 366-384. https://doi.org/10.1080/00336297.2011.10483687.

Abraham, Andrew, David J. Collins, and Russell Martindale. 2006. The Coaching Schematic: Validation through Expert Coach Consensus. Journal of Sports Sciences 24 (06): 549-564.

Abraham, Andrew, Sergio Lorenzo Jiménez. Sáiz, Steve Mckeown, Gareth Morgan, Bob Muir, Julian North, and Kevin Till. 2015. Planning Your Coaching: A Focus on Youth Participant Development. In Practical Sports Coaching, ed. Christine S. Nash, 16-53. New York, NY: Routledge.

Argyris, Chris. 2003. A Life Full of Learning. Organization Studies 24 (7): 1178-1192.

Basham, Brian B. 2014. Police Instructor or Police Educator? Salus Journal 2 (1): 99-109.

Bengoechea, Enrique García, William B. Strean, and D.J. Williams. 2004. Understanding and Promoting Fun in Youth Sport: Coaches' Perspectives. Physical Education \& Sport Pedagogy 9 (2): 197-214. https://doi.org/10.1080/1740898042000294994. 
Beni, Stephanie, Tim Fletcher, and Déirdre Ní. Chróinín. 2017. Meaningful Experiences in Physical Education and Youth Sport: A Review of the Literature. Quest 69 (3): 291-312. https://doi.org/10.1080/ 00336297.2016.1224192.

Biggs, John. 1996. Enhancing Teaching through Constructive Alignment. Higher Education 32 (3): 347-364.

Birzer, Michael L. 2003. The Theory of Andragogy Applied to Police Training. Policing 26 (1): 29-42. https://doi.org/10.1108/13639510310460288.

Braun, Virginia, and Victoria Clarke. 2006. Using Thematic Analysis in Psychology. Qualitative Research in Psychology 3 (2): 77-101. https://doi.org/10.1191/1478088706qp063oa.

Brookfield, Stephen D. 2013. Teaching for Critical Thinking. International Journal of Adult Vocational Education and Technology (IJAVET) 4 (1): 1-15. https://doi.org/10.4018/javet.2013010101.

Brookfield, Stephen D. 2017. Becoming a Critically Reflective Teacher. San Francisco: Jossey-Bass.

Chow, Jia Yi, Keith Davids, Chris Button, and Ian Renshaw. 2016. Nonlinear Pedagogy in Skill Acquisition. London: Routledge.

Christopher, Steve. 2015. The Police Service Can Be a Critical Reflective Practice ... If It Wants. Policing 9 (4): 326-339. https://doi.org/10.1093/police/pav007.

Cushion, Christopher J. 2020. Exploring the Delivery of Officer Safety Training: A Case Study. Policing 14 (1): 166-180. https://doi.org/10.1093/police/pax095.

Cushion, Christopher J., Kathy M. Armour, and Robyn L. Jones. 2003. Coach Education and Continuing Professional Development: Experience and Learning to Coach. Quest 55 (3): 215-230. https://doi. org/10.1080/00336297.2003.10491800.

Farrow, Damian, and Sam Robertson. 2017. Development of a Skill Acquisition Periodisation Framework for High-Performance Sport. Sports Medicine 47 (6): 1043-4057. https://doi.org/10.1007/ s40279-016-0646-2.

Gallimore, Ronald, Wade Gilbert, and Swen Nater. 2014. Ref Lective Practice and Ongoing Learning: A Coach's 10-Year Journey. Reflective Practice 15 (2): 268-288. https://doi.org/10.1080/14623943. 2013.868790 .

Gilbert, Wade, Ronald Gallimore, and Pierre Trudel. 2009. A Learning Community Approach to Coach Development in Youth Sport. Journal of Coaching Education 2 (2): 3-23. https://doi.org/10.1123/ jce.2.2.3.

Jager, Janine, Thimna Klatt, and Thomas Bliesener. 2013. NRW-Studie: Gewalt Gegen Polizeibeamtinnen Und Polizeibeamte [North Rhine-Westphalian Study: Violence against Police Officers]. Kiel: Christian-Albrechts-Universität zu Kiel.

Jakobsson, Britta Thedin, Suzanne Lundvall, and Karin Redelius. 2014. Reasons to Stay in Club Sport According to 19-Year-Old Swedish Participants: A Salutogenic Approach. Sport Science Review 23 (5-6): 205-224. https://doi.org/10.1515/ssr-2015-0002.

Jones, Robyn L., Jake Bailey, and Andrew Thompson. 2013. Ambiguity, Noticing, and Orchestration: Further Thoughts on Managing the Complex Coaching Context. In The Routledge Handbook of Sports Coaching, ed. Paul Potrac, Wade Gilbert, and Jim Denison, 271-283. New York: Routledge.

Kiely, John. 2012. Periodization Paradigms in the 21st Century: Evidence-Led or Tradition-Driven? International Journal of Sports Physiology and Performance 7 (3): 242-250. https://doi.org/10. 1123/ijspp.7.3.242.

Koerner, Swen, and Mario S. Staller. 2021. Police Training Revisited - Meeting the Demands of Conflict Training in Police with an Alternative Pedagogical Approach. Policing 15 (2): 927-938. https://doi. org/10.1093/police/paaa080.

Körner, Swen, and Mario S. Staller. 2018. From System to Pedagogy: Towards a Nonlinear Pedagogy of Self-Defense Training in the Police and the Civilian Domain. Security Journal 31 (2): 645-659. https://doi.org/10.1057/s41284-017-0122-1.

Körner, Swen, and Mario S. Staller. 2019. Zwischen Irritation Und Indifferenz - Die Polizei Als Lernende Organisation? Eine Fallanalyse [Between Irritation and Indifference - The Police as a Learning Organisation? A Case Analysis]. In "Lehren Ist Lernen: Methoden, Inhalte Und Rollenmodelle in Der Didaktik Des Kämpfens" : Internationales Symposium; 8. Jahrestagung Der Dvs Kommission "Kampfkunst Und Kampfsport" Vom 3. - 5. Oktober 2019 an Der Universität Vechta; Abstractband, edited by Martin Meyer and Mario S. Staller, 52-53. Hamburg: Deutsche Vereinigung für Sportwissenschaften (dvs).

Körner, Swen, Mario S. Staller, and André Kecke. 2019. “„Das Ist Anders Geworden...“ - Sichtweisen von Einsatztrainer*innen Auf Polizeianwärter*innen ["Things Have Changed..." - Perspectives of Police Trainers on Police Trainees].” In "Lehren Ist Lernen: Methoden, Inhalte Und Rollenmodelle 
in Der Didaktik Des Kämpfens" : Internationales Symposium; 8. Jahrestagung Der Dvs Kommission “Kampfkunst Und Kampfsport” Vom 3. - 5. Oktober 2019 an Der Universität Vechta; Abstractband, edited by Martin Meyer and Mario S. Staller, 29-30. Hamburg: Deutsche Vereinigung für Sportwissenschaften (dvs).

Kovacs, Louise, and Sarah Corrie. 2017. Building Reflective Capability to Enhance Coaching Practice. The Coaching Psychologist 13 (1): 4-12.

Leary, Mark R., and Robin M. Kowalski. 1990. Impression Management: A Literature Review and TwoComponent Model. Psychological Bulletin 107 (1): 34-47.

Lyle, John. 2002. Sports Coaching Concepts: A Framework for Coaches' Behaviour. New York: Routledge.

Lyle, John. 2018a. Reflecting on the Development of a Conceptual Framework for Sport Coaching. International Sport Coaching Journal 5 (1): 90-98. https://doi.org/10.1123/iscj.2017-0085.

Lyle, John. 2018b. The Transferability of Sport Coaching Research: A Critical Commentary. Quest 6 (2): 1-19. https://doi.org/10.1080/00336297.2018.1453846.

Martindale, Amanda, and David J. Collins. 2012. A Professional Judgment and Decision Making Case Study: Reflection-in-Action Research. The Sport Psychologist 26 (4): 500-518. https://doi.org/ 10.1123/tsp.26.4.500.

Martinie, Marie-Amélie., and Valérie Fointiat. 2006. Self-Esteem, Trivialization, and Attitude Change. Swiss Journal of Psychology 65 (4): 221-225.

McLean, Kyle, Scott E. Wolfe, Jeff Rojek, Geoffrey P. Alpert, and Michael R. Smith. 2019. Police Officers as Warriors or Guardians: Empirical Reality or Intriguing Rhetoric? Justice Quarterly 19 (3): 1-23. https://doi.org/10.1080/07418825.2018.1533031.

Metcalfe, Janet. 2017. Learning from Errors. Annual Review of Psychology 68 (1): 465-489. https:// doi.org/10.1146/annurev-psych-010416-044022.

Morrison, John E, and Larry L Meliza. 1999. Foundations of the After Action Report. United States Army Research Institute for the Behavioural and Social Sciences.

Moy, Brendan, Ian Renshaw, Keith Davids, and Eric Brymer. 2015. Overcoming Acculturation: Physical Education Recruits' Experiences of an Alternative Pedagogical Approach to Games Teaching. Physical Education and Sport Pedagogy 21 (4): 386-406. https://doi.org/10.1080/17408989. 2015.1017455.

Muir, Bob, Andrew Abraham, Gareth Morgan, and Daveid Morley. 2011. Developmentally Appropriate Approaches to Coaching Children. In Coaching Children in Sport, ed. Ian Stafford, 39-59. New York: Routledge.

Muir, Bob, Kevin Till, Andrew Abraham, and Gareth Morgan. 2015. A Framework for Planning Your Practice: A Coach's Perspective. In The Science of Sport Rugby, ed. Kevin Till and Ben Jones, 161-175. Wiltshire: The Crowood Press.

Nota, Paula M., and Di, and Juha-Matti Huhta. 2019. Complex Motor Learning and Police Training: Applied, Cognitive, and Clinical Perspectives. Frontiers in Psychology 10 (August): 167-220. https://doi.org/10.3389/fpsyg.2019.01797.

Otte, Fabian W., Sarah-Kate. Millar, and Stefanie Klatt. 2019. Skill Training Periodization in 'Specialist' Sports Coaching-An Introduction of the 'PoST' Framework for Skill Development. Frontiers in Sports and Active Living 1 (November): 7-17. https://doi.org/10.3389/fspor.2019. 00061.

Piggott, David. 2007. Psychology of Learning and 'Smart Coaching': The Theory behind 'Managing Mistakes.' Insight: The Online Journal of Sport Psychology, January, 80-85.

Rajakaruna, Nikki, Pamela J. Henry, Amy Cutler, and Gordon Fairman. 2017. Ensuring the Validity of Police Use of Force Training. Police Practice and Research 18 (5): 507-521. https://doi.org/ 10.1080/15614263.2016.1268959.

Renden, Peter G., Arne Nieuwenhuys, Geert J P. Savelsbergh, and Raôul. R. D. Oudejans. 2015. Dutch Police Officers' Preparation and Performance of Their Arrest and Self-Defence Skills: A Questionnaire Study. Applied Ergonomics 49: 8-17. https://doi.org/10.1016/j.apergo.2015.01. 002.

Schön, D.A. 1983. The Reflective Practitioner: How Professionals Think in Action. New York: Basic Books.

Shultz, T.R., and Mark R. Lepper. 1996. Cognitive Dissonance Reduction as Constraint Satisfaction. Journal of Personality and Social Psychology 103 (2): 219-240. https://doi.org/10.1037/0033-295x. 103.2.219. 
Smith, Andy, and Michael Parr. 2006. Young People's Views on the Nature and Purposes of Physical Education: A Sociological Analysis. Sport, Education and Society 12 (1): 37-58.

Staller, Mario S. 2021. Optimising Coaching in Police Training [Unpublished Doctoral Dissertation]. Leeds: Leeds Beckett University.

Staller, Mario S., Swen Koerner, Valentina Heil, Andrew Abraham, and Jamie Poolton. 2021a. Police Recruits' Perception of Skill Transfer from Training to the Field. International Journal of Police Science and Management. https://doi.org/10.1177/14613557211064057.

Staller, Mario S., Swen Koerner, Valentina Heil, Andrew Abraham, and Jamie Poolton. 2021b. Police Recruits“ Wants and Needs in Police Training in Germany. Under Review. https://doi.org/10.13140/ rg.2.2.22930.79040.

Staller, Mario S., Swen Koerner, Valentina Heil, Isabel Klemmer, Andrew Abraham, and Jamie Poolton. c. The Structure and Delivery of Police Use of Force Training: A German Case Study. European Journal for Security Research, May, 1-26. https://doi.org/10.1007/s41125-021-00073-5.

Staller, Mario S., and Swen Körner. 2019. "Quo Vadis Einsatztraining? [Quo Vadis Police Training?].” In Die Zukunft Der Polizeiarbeit - Die Polizeiarbeit Der Zukunft - Teil II, edited by Eberhard Kühne, 321-64. Rothenburg: Eigenverlag der Hochschule der Sächsischen Polizei (FH).

Staller, Mario S., Swen Körner, Valentina Heil, and André Kecke. 2019a. Mehr Gelernt Als Geplant? Versteckte Lehrpläne Im Einsatztraining [More Learned than Planed? The Hidden Curriculum in Police Use of Force Training]. In Empirische Polizeiforschung XXII Demokratie Und Menschenrechte - Herausforderungen Für Und an Die Polizeiliche Bildungsarbeit, ed. Bernhard Frevel and Peter Schmidt, 132-149. Frankfurt: Verlag für Polizeiwissenschaft.

Staller, Mario S., Swen Körner, Valentina Heil, Isabel Klemmer, and André Kecke. 2019b. “„War Ne Runde Sache" - Die Reflexive Coaching Praxis von Polizeilichen Einsatztrainer*innen [,It Was a Round Thing" - The Reflective Coaching Practice of Police Trainers]." In Lehren Ist Lernen: Methoden, Inhalte Und Rollenmodelle in Der Didaktik Des Kämpfens : Internationales Symposium; 8. Jahrestagung Der Dvs Kommission "Kampfkunst Und Kampfsport" Vom 3. - 5. Oktober 2019b an Der Universität Vechta; Abstractband, edited by Martin Meyer and Mario S. Staller, 15-16. Hamburg: Deutsche Vereinigung für Sportwissenschaft (dvs).

Staller, Mario S., and Benjamin Zaiser. 2015. Developing Problem Solvers: New Perspectives on Pedagogical Practices in Police Use of Force Training. Journal of Law Enforcement 4 (3): 1-15.

Thomas, Gary. 2011. A Typology for the Case Study in Social Science Following a Review of Definition, Discourse, and Structure. Qualitative Inquiry 17 (6): 511-521. https://doi.org/10.1177/1077800411 409884.

Till, Kevin, Bob Muir, Andrew Abraham, David Piggott, and Jason Tee. 2019. A Framework for Decision-Making within Strength and Conditioning Coaching. Strength and Conditioning Journal 41 (1): 14-26. https://doi.org/10.1519/ssc.0000000000000408.

Tosey, Paul, Max Visser, and Mark NK. Saunders. 2012. The Origins and Conceptualizations of 'Triple-Loop' Learning: A Critical Review. Management Learning 43 (3): 291-307. https://doi.org/10. 1177/1350507611426239.

Trudel, Pierre, Wade Gilbert, and P. Werthner. 2010. Coach Education Effectiveness. In Sport Coaching: Professionalisation and Practice, ed. John Lyle and Christopher Cushion, 135-152. London: Elsevier.

Visek, Amanda J., Sara M. Achrati, Heather M. Mannix, Karen McDonnell, Brandonn S. Harris, and Loretta DiPietro. 2015. The Fun Integration Theory: Toward Sustaining Children and Adolescents Sport Participation. Journal of Physical Activity and Health 12 (3): 424-433. https://doi.org/10. 1123/jpah.2013-0180.

de Vries, Jan, and Fiona Timmins. 2015. Care Erosion in Hospitals: Problems in Reflective Nursing Practice and the Role of Cognitive Dissonance. Nurse Education Today 38 (38): 5-8. https://doi.org/10. 1016/j.nedt.2015.12.007.

Publisher's Note Springer Nature remains neutral with regard to jurisdictional claims in published maps and institutional affiliations. 